\title{
Developing the Writing Ability of Intermediate Language Learners by Blogging
}

\author{
Mohsen Hajiannejad (Isfahan, Iran)
}

\begin{abstract}
Considering the widespread use of blogs during recent years, the present study explored how blogging can affect the writing skill of Iranian language learners. Besides, the learners' perception of blogging was evaluated qualitatively and quantitatively to see whether learners showed enthusiasm to blogging and how it motivated them to write. Two intermediate English classes were selected as the Control and Experimental Groups. Six writing topics were selected and were assigned to both groups. The writing activities in the Control Group were done on paper-based method while the Blogging Group used a selected website to do so. To evaluate the writing activities, four criteria were taken into account: a) length of the writing activities, b) use of verb forms, c) use of articles, and d) use of prepositions. Based on the results of the chi-square tests, in terms of the frequency of missed articles and prepositions the performances of both groups were significantly different. Also the compositions in the Blogging Group were longer than those of the Control Group. However, the qualitative and quantitative evaluation of the learners' perception towards blogging revealed that students believed blogging had encouraged them to write more accurately. They also considered that blogging had remarkably improved their writing ability as compared to the time they did not use blogging.
\end{abstract}

\section{$1 \quad$ Introduction}

Teachers do their best to find ways to help students improve their learning. No doubt, writing is the most difficult skill for language learners to master (Richards/Renandya 2002), consequently teachers should try to help learners produce a coherent, fluent, extended piece of writing which is probably the most difficult thing in this respect (Nunan 1999). Writing is also a way of knowing, a method of discovery and analysis. By writing we discover new aspects of our topic and our relationship to it; therefore it is a task which is partially dependent on the individuals, their creativity and the way they approach each topic.

The ability to write effectively is becoming more and more important and writing instruction is assuming an increasing role in L2 language education (Weigle 2002). From simple writing activities to scientific reports, all depend considerably on the writing skills of an individual. A research paper which is not expressed properly, irrespective of the value it has, may not convey the author's main idea or even might not be valued efficiently while being read by the target readers.

For years, the process approach being affected by Flower and Hayes' theories (1981) and Peter Elbow's views (1990), had been a widely accepted pedagogical approach for writing. This approach was a focus on the recursive process of brainstorming ideas, drafting, organizing, editing, and rewriting. Then Atkinson (2003) defined post-process approach as including everything that follows the period of L2 writing instruction and as an approach mainly focusing on writing as a cognitive, multi-stage process. Nonetheless, since a decade 
ago, writing and technology have focused on a variety of computer applications as well as a variety of tools, from word processors, e-mails, listservs, to online chats, bulletin board discussions, and Web page projects (Jones 2006). During the recent years, by the expansion of the Internet more than ever and accessibility of more affordable computers, a number of new tools have emerged. Most of these tools serve as virtual communities or a cyber environment through which starting new topics and proliferation of the whole community is possible. Such tools have turned to be useful means of creating an online community. Wikis, Open-source Netbooks, and Weblogs are among these tools. Typically these technologies may fulfill educational applications for needs raised every day.

Weblogs (blogs), online personal journals that are frequently updated, have existed in the cyberspace community since 1998 . However, educational blogging only emerged in the early 2000s. The impact of the computer on teaching and learning a language can be traced in all language skills. In spite of numerous approaches to the teaching of writing such as communicative language teaching (CLT), process-based approach, product-based approach, genre-based approach; etc., that have evolved from different teaching methods, tackling EFL writing is still one of the challenging areas for teachers and students (Shokrpour/Fallahzadeh 2007). The recent popularity of blogs over the last couple of years has caused practitioners of language teaching to ponder on the integration of this medium in language learning classrooms. Blogs were created as a tool for people to create online journals without any programming experience or knowledge. Although not originally intended for use in ESL classrooms, blogs have a huge potential as an extremely valuable tool for second language teaching. Some research on EFL/ESL methodology focus on teaching one or two of the English language skills by using computers, such as teaching vocabulary or speaking, while some others have focused on the English language proficiency in general. Not surprisingly, the language skill which may be most affected by the new technology is writing.

Essentially, in traditional paper and pen writing tasks, students can only receive comments about their own writing and that is possible just by the teacher in a non-interactive procedure. While using blogs, commenting on each others' writing would be possible and learners can share their personal thoughts and ideas with each other. Students can also discuss their writing errors, which may lead to an interactive and authentic use of language. This medium gets even a higher degree of importance in non-English speaking countries, due to insufficient exposure of learners to the foreign language outside the class.

Some believe that writing skills do not receive enough attention, as compared to the other skills. The National Commission on Writing in America's Schools and Colleges (2006) in its report included the following action items to compensate for the so called neglected skill, i.e. writing, in education: "(1) double the amount of time students spend writing, (2) assign writing across the curriculum, (3) encourage out-of-school writing, and (4) employ technology to help improve writing" (as cited in Drexler/Dawson/Ferdig 2006: 140). As a result, one might think of blogging as a means to meet these requirements. The findings regarding the use of blogs in writing tasks have shown that it can have numerous outcomes in different situations and for students with a myriad of characteristics. While some researchers like Chang and Chang (2004) and O'Donnell (2006) have reported a positive attitude to it, others like Kelly (2008) and Al-Aayed (2009) have found that it is not of great significance and the students' performances have not been considerably enhanced.

Considering the widespread use of weblogs during the recent years, the use of this medium in language teaching is attracting the attention of researchers in the field of language teaching. At this time, using blogs in education, and particularly in foreign language teaching is still novel and needs more formal studies. 
The present study probed blogging, as one of the most recent technologies in language teaching to find out how it can help intermediate learners in Iran, where English is a foreign language, improve their writing skills, and how it can be applied in the language learning classroom. Besides, effort has been made to find out how students themselves find blogging effective for improving their writing ability.

\section{Background}

Chastain (1988) believes that writing is a fundamental communication skill and a distinct asset in the process of language learning. By the recent advances in technology and emergence of computer-mediated communication (CMC) and weblogs, teachers can think of incorporating weblogs into the classroom to easily make the accessibility of teaching materials possible even outside the classroom. Regarding the nature of weblogs, improvement of writing skills can be the main focus in such activities. Weblogs give students the opportunity for authentic self-expression with writing.

Warschauer (1997) put forward that the potential role of blogs in education, and in second language learning in particular, is revealed through an analysis of the medium's affordances. The value of online communication in second language learning has been attributed to how it combines the interactivity of speech with the permanence of writing.

Campbel (2005) upholds the view that what makes weblogs attractive to EFL/ESL educators is the chance they give to the students to put what they are learning in the classroom to use in expressive and interactive ways. In addition to reading and writing practice, blogs not only allow learners to share their personal thoughts and ideas, but also enable them to meet and interact with people around the world doing the same. The resulting conversations expose learners to authentic uses of the language, stimulating and challenging them in ways that classroom experiences cannot. This is particularly helpful for EFL learners, for whom immersion is difficult.

Richardson (2006) extends an analysis of blogging into a practical guide for teachers trying to integrate blogging into their classes. He suggests a number of benefits of blogging, including increased motivation, intuitive and associational thinking sense of community, combination of solitary and social interaction, and confidence. With a few simple steps in a graphical user interface, teachers can easily use the blog to create a collaborative learning environment in which students can peer edit others' postings (Dieu 2004; Mitchell 2003). Students should be encouraged to comment their partner's postings, which can also be shared by other classmates.

Kelley (2008) believes that updated content is a distinctive feature of blogs, which results in more conversational or interactive experiences, as compared to other types of media on the Web. Basic blogging can be done with little or no computer programming experience whatsoever (Richardson 2006; as cited in Kelley 2008).

The ease of writing and publishing on blogs makes them an appealing medium to students and thus has been found to help increase the quantity of student writing as well as its lexical sophistication (Fellner/Apple 2006). Having students write on blogs can help learners' transition from a more colloquial to an academic writing style, develop a sense of voice, learn to participate in a community of writers, and gain an important new literacy in its own right by becoming contributors to and not just consumers of online content (Bloch 2007; Rezaee/Oladi 2008).

At first glance it might seem that Weblogs give students the opportunity for authentic selfexpression with writing. Meanwhile, different learners with a variety of social backgrounds may react differently to using computers in general, and expressing their ideas in an interactive environment where everyone can access their pieces of writing and yet write comments about them. What needs stressing is that there is a variety of aspects for Weblogs 
to be considered. But the current study sought to investigate about the following two directional hypotheses:

Hypothesis (1) There is a relation between using weblogs and the improvement of the writing skill.

Hypothesis (2) Writing in the virtual environment of weblogs can affect the students' perception for developing their writing skills.

\section{$3 \quad$ Methodology}

\subsection{Participants}

Two classes of intermediate English learners were randomly selected from among five firstgrade intermediate classes, held at Kish Institute of Science and Technology in Tehran, Iran. One class was labeled as the Control Group and the other as the Experimental Group (blogging group). In brief, the participants of the study were twenty male adult language learners, aged between 20 and 27, 10 learners in each class. The decision about number of participants was somewhat constrained because there were only ten students in the Experimental Group; accordingly ten students were also randomly selected from among the total of fifteen students in the Control Group. In order to maintain the validity of the data, the five students not being part of the study were not notified that they were excluded. Hence in the Control Group, all of the students were required to do the writing tasks being assigned to them and received feedback on them, while only the results obtained from the selected ten were included in the study. By the way, the special circumstances of this study in terms of the homogeneity of the participants, lead to a small number of students in both groups. Accordingly, the results were limited and could not be generalized to larger groups.

An important concern in the selection of the classes was the homogeneity of students in terms of their English proficiency. Regarding the issues of language proficiency, the researcher relied on the Preliminary English Test (PET) which is a standard test of Cambridge ESOL and is employed by the selected language institute. The students in both classes had taken and passed PET at the end of their previous term and had scored above 70\%. Moreover, the students in both classes were learning English as a Foreign Language and did not receive much input outside their classrooms. In terms of motivation, all of them were intrinsically motivated, based on the teacher's direct inquiry at the first session.

\subsection{Materials}

For the current study six writing topics were selected from among the topics of the textbook being taught to both groups as part of the syllabus prescribed by the curriculum designers of the institute (Total English). The researcher found these topics appropriate for the current study since they did not include abstract concepts and were not complicated. Moreover, by selection of the topics from the textbook, the normal class activities were not interrupted. The topics were as follows:

1. Describe characteristics of a good friend.

2. Advantages and disadvantages of new technologies.

3. How will jobs change in the next decade?

4. What one should and should not do in a job interview?

5. What are the most important inventions of the last century?

6. Describe how globalization has changed the world. 
The selected website for this study was www.englishclub.edublogs.org (accessed December 9, 2012), which was a website specially designed for educational purposes and the blogger was provided with useful tools. Hence it was easy to follow a thread and post their writing activities, which might prompt comments from readers. Moreover, in this website, in order for a post to go on the blog first the administrator's permission was acquired which prevented unwanted posts by non-Experimental Group members. On top of that, the researcher who was also the website administrator, could monitor the activities and discussions of the members, control the whole content of the website in order to avoid irrelevant posts, and even change the appearance of the website. In addition, as soon as a new comment was posted by a leaner, the website administrator, was sent a notification email automatically, as a result the learners would not wait a long time for their posts to be confirmed and attended to by the researcher. Therefore, generally, the researcher could very well manage the website. As another aspect of this website, the topics were chronologically ordered so that at the end of the semester each learner could easily follow his performances all through the semester and find out how he has made improvements.

Also, three questionnaires were used to elicit the students' attitudes - qualitatively and quantitatively - as will be explained in detail in the following sections.

\subsection{Procedure}

\subsubsection{Pilot Study}

In order to locate any probable unpredicted problems in the process of blogging, a pilot study was conducted in which only two topics were assigned to a class similar to the Experimental Group and the students were supposed to post their writings on the website of the current study. To do so, firstly they were informed about signing up for a new account at the weblog to become a member; but some of them could not successfully sign up for a new account themselves. In order to avoid this problem in the main study, the researcher decided to use a feature of the selected weblog thereafter; i.e. creating a new account for each student and subscribing them by email. Thus, the students in the Experimental Group would be able to join the weblog by a simple click on a link sent to them by email.

When the first topic was assigned to the students, a number of them did not post their writing tasks on time, so the teacher needed to wait in order to receive them all and then assign the second topic and this could hinder the procedure of the main study. To avoid this problem, before assigning the first writing task, the students in the Experimental Group were briefed about the importance of this activity. They were informed that each writing activity would be $5 \%$ of their final score.

In the pilot study every time that the teacher wanted to post a new topic, he just informed them in the class to check the blog. It was the case that a student was absent on the day the teacher wanted to assign the second topic, so he was not notified about it. To overcome a similar problem in the main study, the researcher decided to take two trends. First of all he decided to assign a new topic every other session in order to finish the study in the shortest time possible. He also informed the students at the outset that whenever a new topic was assigned, a notification email would be sent to them. So even if they were absent, they were required to do the writing tasks. Although it could not totally overcome the issue of absentees, it was a good way to diminish it.

\subsubsection{Main Procedure}

The Experimental and Control groups met from 4:30 to 6:15 p.m. daily except Thursdays. The whole process of the main study took 13 sessions. 
When the teachers in both classes felt that the textbook had been covered enough and the students were ready to do the first writing task, the Control Group was assigned to write a composition about the first topic and hand in their writing tasks the following session. In the third session the teacher collected the compositions, corrected them against a set of criteria which will be explained later in this part, and returned them to their writers in the fourth session. At the end of the fourth session, the teacher assigned the second writing topic and continued with the same procedure until writing on all the six topics were done and feedback on all compositions was provided. In other words, at the end of the thirteenth session the students received feedback on their last writing task.

The procedure in the Experimental Group ran parallel to that of the Control Group. With respect to the results of the pilot study, in the first session, the students in the Experimental Group were asked to give their teacher their email addresses. Also in the first session the teacher, using the Office Power Point software, showed the participants in the Experimental Group a demo version of the whole procedure; i. e. becoming a member of the weblog, posting a composition and commenting on other participants' compositions.

In the second session, having had all the students in the Experimental Group sign up for a weblog account, they were assigned the first writing topic and were asked to post their assignments on the weblog before the following session. Whenever a new composition was posted, it did not appear immediately on the weblog, but the approval of the website administrator (i.e. the researcher) was required for it in order to appear on the weblog. This feature gave the researcher more dominance on the blog in order to allow posts only from members of the Experimental group. It took about an hour for a post to appear on the weblog; meanwhile, the researcher could read each composition and provide the students with feedback. The students had enough time to read each others' compositions and leave comments in case they wanted to.

The students posted their first composition and went through all the procedures explained above. Following the same procedure, the other five topics were assigned every other session and at the end of the thirteenth session feedback was provided for the final composition.

The results were analyzed against a list of preset touchstones, which enabled the researcher to compare the performances of the Control and Experimental Groups at the final composition.

Furthermore, the attitudes of the learners who used blogging were analyzed qualitatively and quantitatively through questionnaires to find out what their perception was about weblogs for developing their writing skills.

\subsection{Evaluation Procedure}

\subsubsection{Quantitative Evaluation of Learners' Performances}

To evaluate the writing activities, four criteria were taken into account: a) length of the writing activities, b) use of verb forms, c) use of articles, and d) use of prepositions. These criteria were selected since they are quantifiable and the rater's personal ideas could not affect the writing reports. Moreover, it should be acknowledged that the results only revealed the potential differences of the Control and Experimental Groups in terms of these criteria rather than a score which is based on the quality of a writing. For this purpose, the researcher analyzed seven aspects of the above-mentioned criteria by examining the following elements in the writing tasks:

1. Missing verb forms.

2. Incorrectly used verb forms.

3. Missing articles. 
4. Incorrectly used articles.

5. Missing prepositions.

6. Incorrectly used prepositions.

7. The number of words in each writing task.

The evaluation process included two main parts. To begin, the first and last performances of each group were compared together; then the performances of the Blogging and Control Groups were compared with each other in the first and last writing tasks.

In order to find out if the performances of each group in their first composition were significantly different from those of their last composition, twelve Chi-square tests were performed, taking the above-mentioned benchmarks into consideration. Accordingly, the analysis of the data which compromised of six Chi-square tests at $\alpha=0.05$ was conducted for each group. Moreover, the means of the number of words produced by the learners in each group were compared. It is noteworthy that these Chi-square tests, would only indicate if the participants of the Control and Experimental Groups performed differently within their own respective groups by comparing their first session's performances to those of their last session's.

However, it was imperative to compare the performances of the participants of the Control Group to those of the Experimental Group in order to identify any probable differences between the groups in the first and last compositions. So the researcher performed six Chisquare tests between the performances of both groups in their first performances, the results of which could indicate if both groups were different at the outset. Moreover, the researcher needed to find out whether going through the blogging procedure had affected the performances of the participants of the Experimental Group as compared with those of the Control Group. So, the researcher also carried out six Chi-square tests between the performances of the Control and Experimental groups in their last writing tasks.

All in all, twenty-four Chi-square tests were carried out to check significant differences in both intra-group and inter-group performances.

\subsubsection{Qualitative Evaluation of Learners' Perceptions towards Blogging}

To study the perception of EFL learners about weblogs for developing their writing ability, providing the learners with feedback about their last composition, the learners in the Blogging group were firstly asked to provide a written comment on their experience with their writing task through blogging, the results of which were analyzed qualitatively.

In the last session of the course, the learners' perception in the Experimental Group was evaluated about blogging. This part included two questioners and was conducted in Persian, the students' mother tongue, to avoid any complexities and worries about the use of language. First, they were asked to talk about their feelings freely (Appendix 1) and then they were asked to answer some questions in detail (Appendix 2). In order to be able to analyze the results of all the questioners given to an individual in relation to one another, the students were asked to put their names on the sheets given to them. They were assured that all the information would remain confidential.

In order to avoid directing the students' minds towards the issues presented in the second questionnaire (Appendix 2), the learners initially were asked to write about their experience freely (Appendix 1); it was then that they were given the second questionnaire in which they were asked about different aspects of blogging. If at the outset the students had been given the second questionnaire, then they were asked to describe their feelings freely some of them would probably mention their comments according to the issues they had encountered before. 
So it could limit the total expression of their feeling towards blogging and the whole procedure they had gone through.

\subsubsection{Quantitative Evaluation of Learners' Perception towards Blogging}

To conduct the quantitative evaluation of the learners' perception towards blogging, they were given a Likert Scale questionnaire (Appendix 3). In this part of the study the main concern was to reach some clear answers about students' perception towards blogging and their level of acquaintance with the Internet in general and blogging in specific. So the researcher was able to analyze the answers with respect to the previous evaluation parts and also could investigate whether different factors, such as the learners' computer skills, affected their ideas about the procedure they had undergone.

\section{$4 \quad$ Results}

In this part the results obtained from the performances of both, the Experimental and Control Groups will be introduced and tables and graphs will be presented. The results generally comprised two sets of twelve inter-group and intra-group Chi-square tests, besides the mean number of words produced by the learners were compared. At first six Chi-square tests were conducted between the first and last composition of the Control and Experimental Groups making a total number of twelve Chi-square tests. Then six Chi-square tests were conducted between the performances of the Control Group as compared to those of the Experimental Group in the first composition, and finally six Chi-square tests were conducted between the performances of the Control Group as compared to those of the Experimental Group in the last composition. At the end, the hypotheses will be examined with regards to the obtained data. Moreover, the results attained from qualitative evaluation of the learners' perception towards blogging will be explained in detail.

\subsection{The Results of the Chi-Square Tests for the First Composition}

In order to find out whether there was a significant difference between the two groups in the beginning of the study, besides relying on the results of a standard test (i. e., PET), the first compositions were analyzed for their length, verb forms, articles, and preposition. Consequently six Chi-square tests were carried out for each group at $\alpha=0.05$ and the mean number of words produced by the learners in each group were compared. Table 1 indicates the results emanated from the performances of the groups after writing the first composition, in seven areas.

\begin{tabular}{|c|c|c|c|c|c|c|c}
\hline $\begin{array}{c}\text { Particip } \\
\text { ant }\end{array}$ & $\begin{array}{c}\text { Frequency } \\
\text { of missed } \\
\text { verb } \\
\text { forms }\end{array}$ & $\begin{array}{c}\text { Frequen- } \\
\text { cy of } \\
\text { wrong } \\
\text { verb } \\
\text { forms }\end{array}$ & $\begin{array}{c}\text { Frequen- } \\
\text { cy of } \\
\text { missed } \\
\text { articles }\end{array}$ & $\begin{array}{c}\text { Freque- } \\
\text { ncy of } \\
\text { wrong } \\
\text { articles }\end{array}$ & $\begin{array}{c}\text { Frequen- } \\
\text { cy of } \\
\text { missed } \\
\text { prepositi } \\
\text { ons }\end{array}$ & $\begin{array}{c}\text { Frequen- } \\
\text { cy of } \\
\text { wrong } \\
\text { prepositi } \\
\text { ons }\end{array}$ & $\begin{array}{c}\text { Num- } \\
\text { ber of } \\
\text { words }\end{array}$ \\
\hline \multicolumn{7}{|c|}{ Blogging Group } \\
\hline 1 & 1 & 1 & 2 & 1 & 2 & 1 & 124 \\
\hline 2 & 0 & 4 & 1 & 2 & 1 & 0 & 87 \\
\hline 3 & 0 & 2 & 0 & 2 & 1 & 1 & 140 \\
\hline 4 & 1 & 3 & 2 & 1 & 2 & 0 & 102 \\
\hline 5 & 0 & 2 & 1 & 0 & 1 & 0 & 118 \\
\hline
\end{tabular}



by Blogging

\begin{tabular}{|c|c|c|c|c|c|c|c|}
\hline 6 & 0 & 2 & 2 & 1 & 0 & 0 & 120 \\
\hline 7 & 1 & 0 & 0 & 1 & 1 & 1 & 105 \\
\hline 8 & 0 & 2 & 2 & 0 & 2 & 0 & 77 \\
\hline 9 & 0 & 2 & 1 & 1 & 0 & 2 & 112 \\
\hline 10 & 1 & 4 & 1 & 1 & 0 & 1 & 127 \\
\hline \multicolumn{8}{|c|}{ Control Group } \\
\hline 1 & 1 & 3 & 0 & 1 & 1 & 2 & 100 \\
\hline 2 & 2 & 1 & 0 & 1 & 0 & 0 & 105 \\
\hline 3 & 0 & 2 & 2 & 0 & 2 & 0 & 102 \\
\hline 4 & 0 & 2 & 3 & 1 & 2 & 0 & 80 \\
\hline 5 & 0 & 1 & 1 & 2 & 3 & 1 & 112 \\
\hline 6 & 0 & 1 & 2 & 0 & 1 & 0 & 110 \\
\hline 7 & 1 & 4 & 1 & 0 & 2 & 0 & 95 \\
\hline 8 & 0 & 0 & 1 & 1 & 0 & 1 & 110 \\
\hline 9 & 1 & 2 & 1 & 0 & 2 & 1 & 120 \\
\hline 10 & 1 & 1 & 2 & 1 & 1 & 0 & 115 \\
\hline
\end{tabular}

Table 1: The Results of the Learners' Performances in the First Writing Composition

\begin{tabular}{cccc}
\hline & $\begin{array}{c}\text { Blogging Group } \\
\text { (First } \\
\text { Composition) }\end{array}$ & $\begin{array}{c}\text { Control Group } \\
\text { (First } \\
\text { Composition) }\end{array}$ & $\chi^{2}$ \\
\hline $\begin{array}{c}\text { Frequency of } \\
\text { missed verb } \\
\text { forms }\end{array}$ & 4 & 6 & 0.54 \\
$\begin{array}{c}\text { Frequency of } \\
\text { wrong verb } \\
\text { forms }\end{array}$ & 22 & 17 & 0.28 \\
$\begin{array}{c}\text { Frequency of } \\
\text { missed articles }\end{array}$ & 12 & 13 & 0.07 \\
$\begin{array}{c}\text { Frequency of } \\
\text { wrong articles }\end{array}$ & 10 & 7 & 1.28 \\
$\begin{array}{c}\text { Frequency of } \\
\text { missed } \\
\text { prepositions }\end{array}$ & 10 & 14 & 1.14 \\
$\begin{array}{c}\text { Frequency of } \\
\text { wrong } \\
\text { prepositions }\end{array}$ & 6 & 5 & 0.20
\end{tabular}




\begin{tabular}{ccc}
\hline & & \\
\hline $\begin{array}{c}\text { Number of } \\
\text { participants }\end{array}$ & $\mathbf{1 0}$ & $\mathbf{1 0}$ \\
\hline $\begin{array}{c}\text { Mean of } \\
\text { produced words }\end{array}$ & 111.20 & 104.90 \\
\hline $\begin{array}{c}* d f=1 \\
* * \alpha=0.05\end{array}$ &
\end{tabular}

Table 2: The Results of the Chi-Square Tests for the First Writing Composition of the Blogging and Control Groups

For the data in this section, a Chi-square test was applied. Table 2 illustrates the results of the Chi-Square Tests for the first composition between the two groups, and Figure 1 shows its graphic presentation.

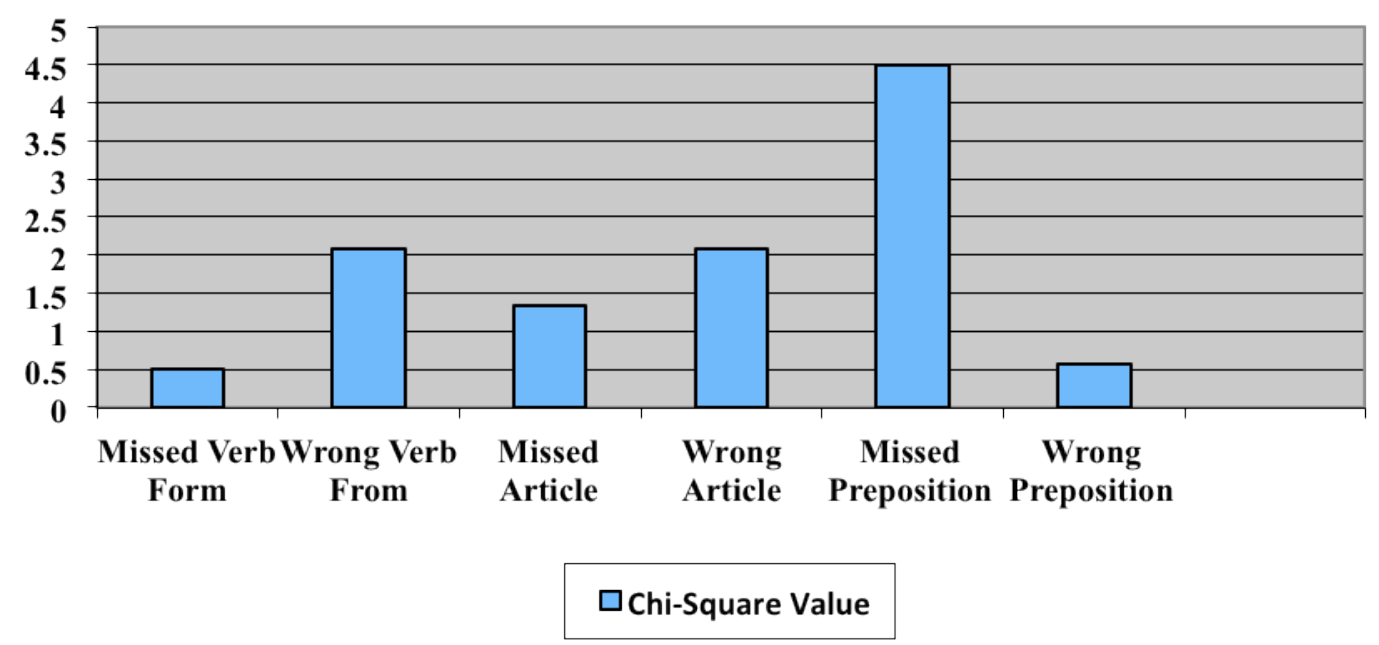

Figure 1: The Graphic Presentation of the Chi-Square Value for the First and Last Composition of the Control Group

By referring to Table 2, it can be noticed that, although there are some differences between the two groups regarding the six features, the difference between the values of Chi-square tests are not statistically significant. Moreover, the mean number of words produced by participants of each group is nearly the same. Therefore, it can be assumed that both groups started with almost the same level of English proficiency.

\subsection{The Results of the Chi-Square Tests between the First and Last Compositions in Each Group}

In order to find out whether there had been a significant progress in the writing performances of each group, the first and last writing performances were compared by applying six Chisquare tests for each group at $\alpha=0.05$, and contrasting the mean of the produced words by each group. The seven features in the last performances of both groups are presented in Table 3.

Taking the information in Table 3 into consideration, six Chi-square tests were conducted for the performances of the Blogging Group in order to find out if the performances in the last composition were significantly different from those of the first composition. Table 4 shows the results of these tests for the Blogging Group, and Figure 2 shows its graphic presentation.

Table 4 is indicative of the fact that the performances of the learners, while comparing their first and last compositions, were not the same. The results show that the performances had 
been improved; however, only the frequency of wrong verb forms, missed prepositions and articles had significantly changed. The length of the last compositions in the Blogging Group was also remarkably higher from that of the first compositions. In other words, the results reveal that the Blogging Group had improved their writing performances in their last composition.

\begin{tabular}{|c|c|c|c|c|c|c|c|}
\hline $\begin{array}{c}\text { Partic- } \\
\text { ipant }\end{array}$ & $\begin{array}{c}\text { Frequency } \\
\text { of missed } \\
\text { verb } \\
\text { forms }\end{array}$ & $\begin{array}{c}\text { Frequen- } \\
\text { cy of } \\
\text { wrong } \\
\text { verb } \\
\text { forms }\end{array}$ & $\begin{array}{l}\text { Frequen- } \\
\text { cy of } \\
\text { missed } \\
\text { articles }\end{array}$ & $\begin{array}{c}\text { Frequen- } \\
\text { cy of } \\
\text { wrong } \\
\text { articles }\end{array}$ & $\begin{array}{c}\text { Frequen- } \\
\text { cy of } \\
\text { missed } \\
\text { prepositio } \\
\text { ns }\end{array}$ & $\begin{array}{c}\text { Frequen- } \\
\text { cy of } \\
\text { wrong } \\
\text { prepositio } \\
\text { ns }\end{array}$ & $\begin{array}{l}\text { Num- } \\
\text { ber of } \\
\text { words }\end{array}$ \\
\hline \multicolumn{8}{|c|}{ Blogging Group } \\
\hline 1 & 1 & 1 & 0 & 3 & 0 & 1 & 156 \\
\hline 2 & 0 & 0 & 0 & 0 & 0 & 0 & 176 \\
\hline 3 & 1 & 0 & 1 & 0 & 0 & 0 & 120 \\
\hline 4 & 0 & 0 & 2 & 1 & 0 & 0 & 192 \\
\hline 5 & 1 & 1 & 0 & 1 & 0 & 1 & 178 \\
\hline 6 & 0 & 2 & 0 & 0 & 1 & 0 & 145 \\
\hline 7 & 0 & 1 & 1 & 0 & 1 & 2 & 166 \\
\hline 8 & 0 & 1 & 1 & 2 & 0 & 0 & 177 \\
\hline 9 & 0 & 1 & 1 & 1 & 0 & 0 & 157 \\
\hline 10 & 0 & 2 & 0 & 1 & 0 & 1 & 189 \\
\hline \multicolumn{8}{|c|}{ Control Group } \\
\hline 1 & 0 & 0 & 1 & 1 & 0 & 1 & 102 \\
\hline 2 & 2 & 1 & 2 & 2 & 1 & 0 & 75 \\
\hline 3 & 2 & 1 & 2 & 2 & 1 & 0 & 117 \\
\hline 4 & 0 & 2 & 1 & 0 & 0 & 1 & 102 \\
\hline 5 & 1 & 4 & 4 & 2 & 1 & 0 & 84 \\
\hline 6 & 1 & 0 & 1 & 3 & 1 & 2 & 117 \\
\hline 7 & 0 & 2 & 2 & 0 & 1 & 0 & 100 \\
\hline 8 & 1 & 1 & 1 & 2 & 2 & 1 & 115 \\
\hline 9 & 0 & 0 & 1 & 0 & 0 & 1 & 98 \\
\hline 10 & 1 & 1 & 3 & 0 & 1 & 1 & 106 \\
\hline
\end{tabular}

Table 3: The Results of the Learners' Performances on the Last Writing Task 


\begin{tabular}{|c|c|c|c|}
\hline & $\begin{array}{c}\text { Blogging } \\
\text { Group (First } \\
\text { Composition) }\end{array}$ & $\begin{array}{c}\text { Blogging } \\
\text { Group (Last } \\
\text { Composition) }\end{array}$ & $\chi^{2}$ \\
\hline $\begin{array}{l}\text { Frequency of } \\
\text { missed verb } \\
\text { forms }\end{array}$ & 4 & 3 & 0.33 \\
\hline $\begin{array}{l}\text { Frequency of } \\
\text { wrong verb } \\
\text { forms }\end{array}$ & 22 & 9 & 18.77 \\
\hline $\begin{array}{l}\text { Frequency of } \\
\text { missed articles }\end{array}$ & 12 & 6 & 6 \\
\hline $\begin{array}{l}\text { Frequency of } \\
\text { wrong articles }\end{array}$ & 10 & 9 & 0.11 \\
\hline $\begin{array}{l}\text { Frequency of } \\
\text { missed } \\
\text { prepositions }\end{array}$ & 10 & 2 & 32 \\
\hline $\begin{array}{l}\text { Frequency of } \\
\text { wrong } \\
\text { prepositions }\end{array}$ & 6 & 5 & 0.20 \\
\hline $\begin{array}{c}\text { Number of } \\
\text { participants }\end{array}$ & 10 & 10 & \\
\hline $\begin{array}{c}\text { Mean of } \\
\text { produced words }\end{array}$ & 111.20 & 165.60 & \\
\hline
\end{tabular}

Table 4: The Results of the Chi-Square Tests for the First and Last Writing Tasks of the Blogging Group

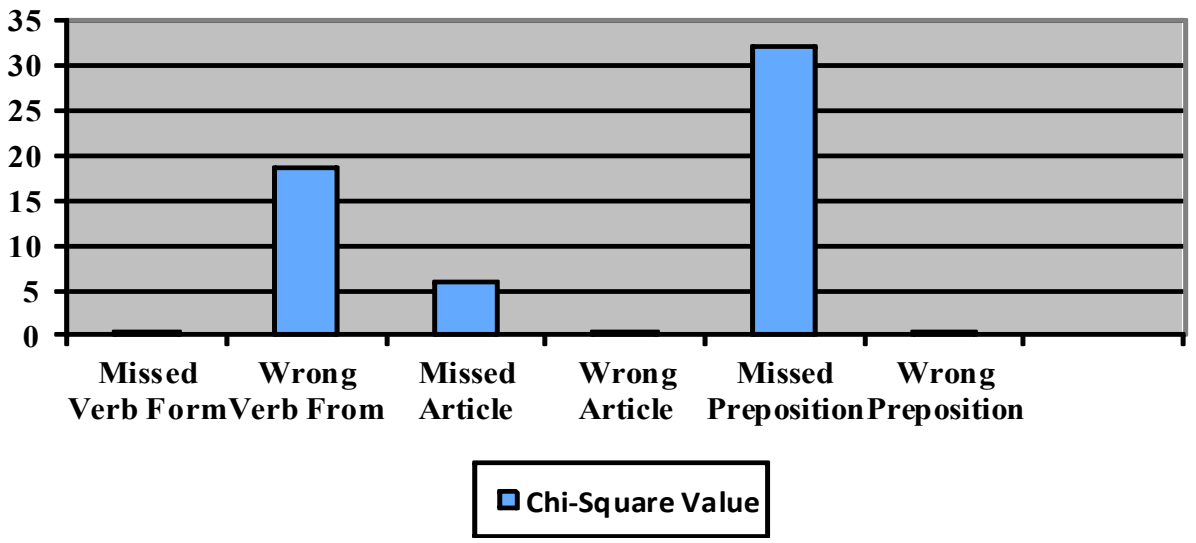

Figure 2: The Graphic Presentation of the Chi-Square Results for the First and the Last Compositions within the Blogging Group

In order to delve into the Control Group's performances, the same procedure was conducted. Table 5 manifests the statistical computation of the Control Group, regarding the first and last 
composition, as well as the results of the Chi-square tests. Figure 3 also depicts the value of the Chi-square tests in this group.

Table 5 demonstrates that the Control Group's performances on the first and last compositions had some differences. The frequency of wrong verb forms, and missed prepositions had improved in the last composition; moreover, the last compositions were longer. Nonetheless, it was only in case of the frequency of missed prepositions that they performed significantly different.

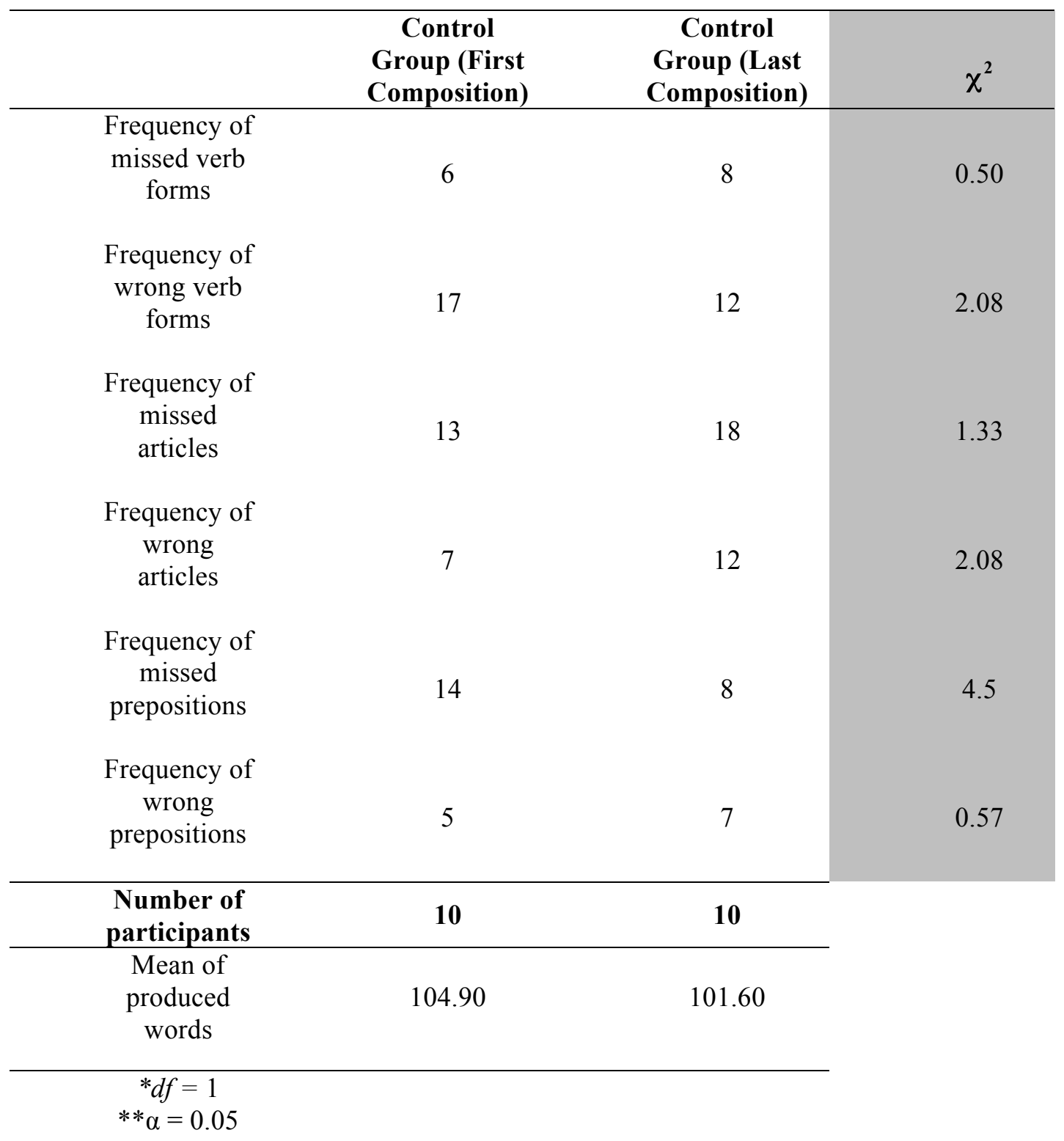

Table 5: The Results of the Chi-Square Tests for the First and the Last Compositions of the Control Group 


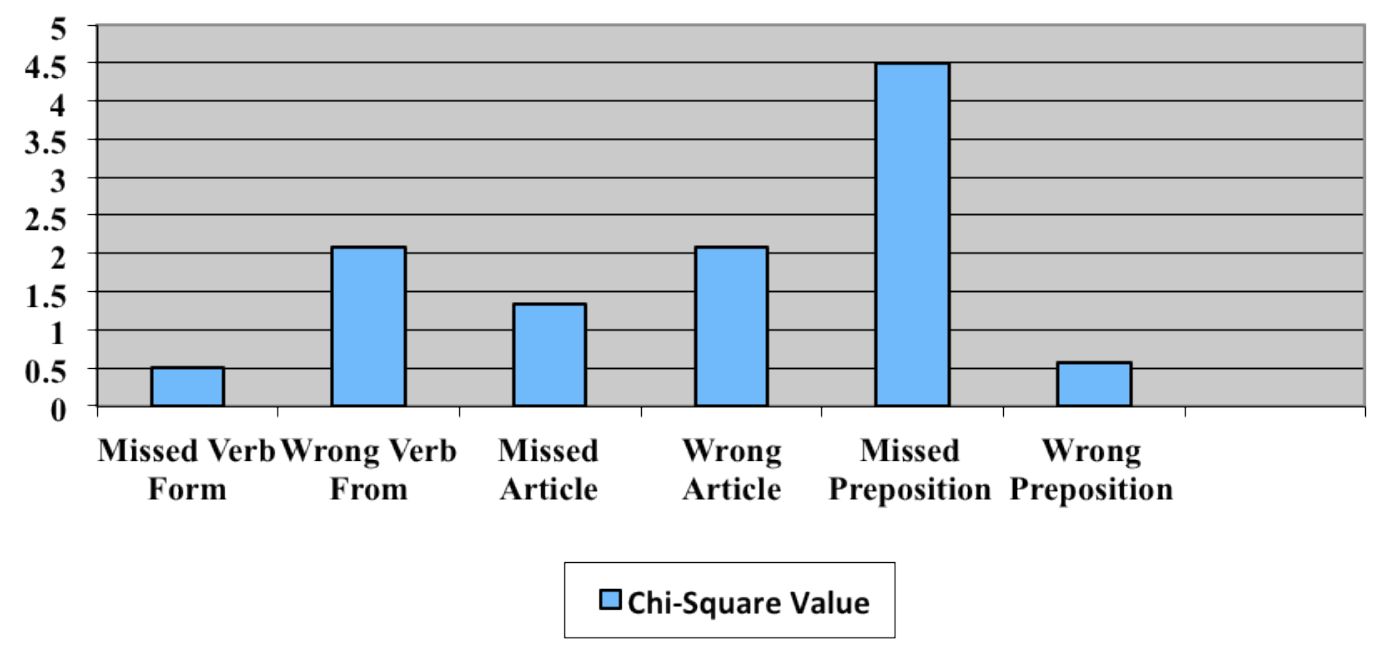

Figure 3: The Graphic Presentation of the Chi-Square Value for the First and Last Composition of the Control Group

\subsection{The Results of the Chi-Square Tests for the Last Composition}

To find out if blogging had a useful impact on the improvement of the learners' writing skills, the results of the last composition in the Blogging Group were compared to those of the Control Group. In order to do so, six Chi-square tests were applied to the data and also the mean of the produced words by the participants in each group were compared. Table 6 shows the statistical computations, and the results of the Chi-square tests. Figure 4 is also the graphic presentation of the Chi-square values.

\begin{tabular}{|c|c|c|c|}
\hline & $\begin{array}{c}\text { Blogging } \\
\text { Group (Last } \\
\text { Composition) } \\
\end{array}$ & $\begin{array}{c}\text { Control } \\
\text { Group (Last } \\
\text { Composition) } \\
\end{array}$ & $\chi^{2}$ \\
\hline $\begin{array}{l}\text { Frequency } \\
\text { of missed } \\
\text { verb forms }\end{array}$ & 3 & 8 & 3.12 \\
\hline $\begin{array}{l}\text { Frequency } \\
\text { of wrong } \\
\text { verb forms }\end{array}$ & 9 & 12 & 0.75 \\
\hline $\begin{array}{c}\text { Frequency } \\
\text { of missed } \\
\text { articles }\end{array}$ & 6 & 18 & 8.00 \\
\hline $\begin{array}{l}\text { Frequency } \\
\text { of wrong } \\
\text { articles }\end{array}$ & 9 & 12 & 0.75 \\
\hline $\begin{array}{l}\text { Frequency } \\
\text { of missed } \\
\text { prepositions }\end{array}$ & 2 & 8 & 4.50 \\
\hline $\begin{array}{l}\text { Frequency } \\
\text { of wrong } \\
\text { prepositions }\end{array}$ & 5 & 7 & 0.57 \\
\hline Number of & 10 & 10 & \\
\hline
\end{tabular}




\begin{tabular}{ccc}
\hline participants & & \\
\hline $\begin{array}{c}\text { Mean of } \\
\text { produced } \\
\text { words }\end{array}$ & 165.6 & 101.6 \\
& & \\
$* d f=1$ & & \\
$* *=0.05$ & &
\end{tabular}

Table 6: The Results of the Chi-Square Tests of the Blogging and Control Groups for the Last Writing Task

From Table 6 and Figure 4, one can easily understand that the groups performed differently on their last composition as compared with their performances on the first composition. It is evident that the Blogging Group had outperformed the Control Group in all the six areas. But the results of the Chi-square tests show that only in terms of the frequency of missed articles and prepositions the performances were significantly different. Also the length of the writing compositions in the Blogging Group was significantly higher than that of the Control Group.

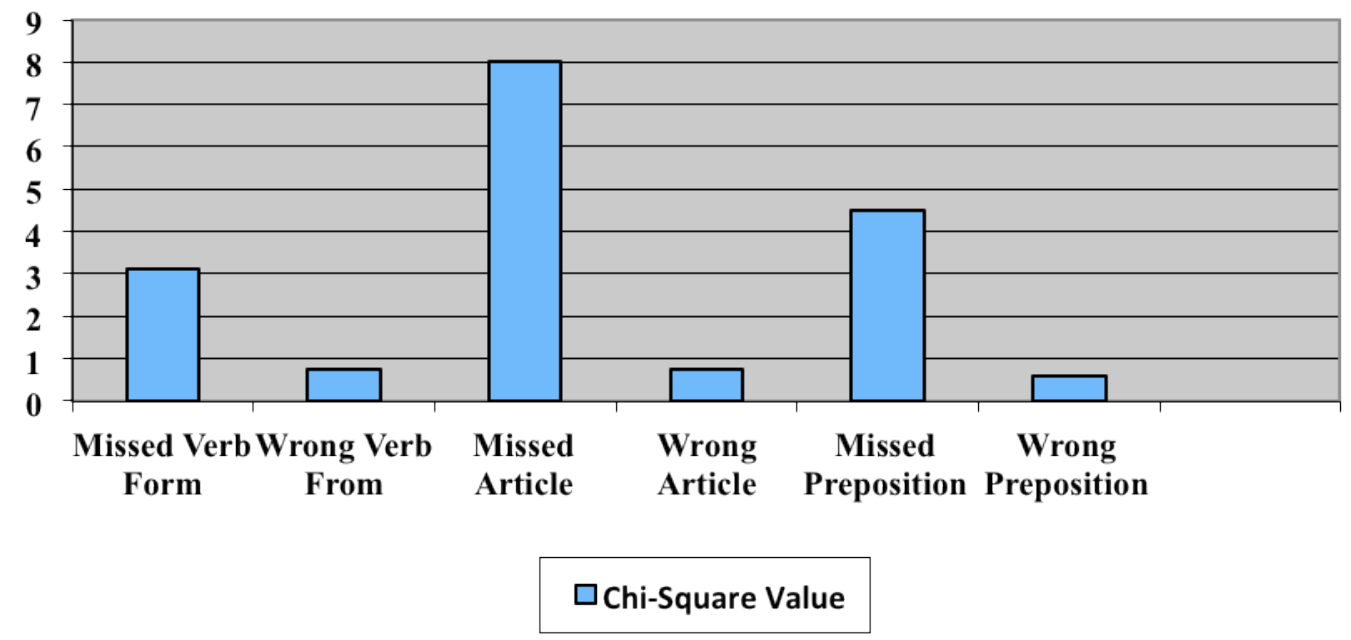

Figure 4: The Graphic Presentation of the Chi-Square Value of the Control and Blogging Groups for the Last Composition

\subsection{The Results of the Qualitative Evaluation of the Learners' Perception towards Blogging}

In order to evaluate the learners' perception about blogging qualitatively, in the last session of the course the students in the Experimental Group were given two questionnaires. In the first questionnaire they were asked to describe their feelings about using weblogs for doing their assignments. In the same session, they were also given a set of open-ended questions to answer.

The answers to the first questionnaire can be put into three main categories; the general ideas of the learners towards blogging, the difficulties they encountered, and the advantages of this tool.

The learners were asked about their occupation in the first questionnaire, in order to figure out how far people with different occupations felt different about Blogging. The answers to this questionnaire showed that almost all of the students found blogging as an interesting and useful activity. So, occupation did not seem to have a decisive role in this study in terms of the participants' feelings towards blogging, and generally all the students claimed to have a positive feeling towards blogging. Some indicated that at first they had not found blogging as 
an appealing activity; however, by continuing to post their compositions on the weblog they changed their mind.

Some students reported a number of issues which sporadically caused problems for them such as not having access to the Internet during the day, and being not good at typing. But no more negative feelings or difficulties were observed in this part.

Most of the students addressed numerous advantages of blogging. Almost all of the learners stated that blogging enabled them stay in touch with their classmates outside the classroom, which they had never experienced before. Going through all the answers, no claims were observed to support the idea that receiving feedback for compositions could embarrass a learner. On the contrary the learners claimed to be encouraged to learn from mistakes committed by others. A student said that in paper and pen writing tasks, it usually took a rather long time to receive feedback on his performances, while it was not the case for the weblogs. Two of the students mentioned that they usually could not keep all their compositions and it was difficult for them to review all their mistakes, but by using weblogs they were able to do so very easily.

As the second phase of the qualitative evaluation of the learners' perception towards blogging, another questionnaire was given to the learners (Appendix 2). In this part the researcher looked for some specific information. This questionnaire was different from the previous one, as it required the students to answer some straightforward questions so it was more systematic.

The first question dealt with the usefulness of blogging from the students' points of view, according to which all of the students had a positive viewpoint in this regard. They believed that it motivated them to be more accurate and generally it was believed to be an interesting activity which they had never experienced before. A student stated that "blogging helped me keep records of all my writing activities, my mistakes and those of my classmates".

As for the second question, the students were asked whether they liked to continue using weblogs for their routine class activities. The answers to this question revealed that some students felt totally satisfied with it, while others thought that at first it had been difficult for them to do their assignments in a weblog. However, having been familiarized with this activity, they felt better and enjoyed it.

Then they were asked what they liked the most about blogging. All the students almost unanimously agreed that blogging made them learn from one another, either from sound structures or from committed mistakes. It was also believed that using the computer to do assignments could help in avoiding piles of papers.

The next question aimed to find out what the students did not like about blogging. In this part they pointed out some of the problems they had encountered such as having low bandwidth of the Internet and not being able to type fast enough which made this activity to be time taking. Some others asserted that at the beginning the whole process was vague for them, so they were bewildered and it was unpleasant for them.

Afterwards they were asked to explain how they benefitted from blogging, if they ever did. The students mostly acknowledged that blogging enabled them stay in touch with their teacher and it was the most prominent aspect of it. Moreover, they believed that blogging helped them improve their writing ability and they felt that it was a successful experience. Four of the learners believed that the integration of new technologies into the classroom was necessary and it was the first time they were experiencing it.

At last the learners were asked to mention their suggestions for using modern technologies in their courses. They agreed that it could be advantageous to continue blogging in long terms 
and suggested that it should be used in all classes of the language institute. Some of them also suggested that using computers inside the classroom and even for their final exams could be a good idea, because they believed that it could help them to get used to the format of some standard tests like TOEFL (CBT or iBT version). One student suggested that holding videoconferences in English by some available computer programs like MSN, Skype and Oovoo, could help them substantially.

\subsection{The Results of the Quantitative Evaluation of Learners' Perception towards Blogging}

As explained in the previous chapter, to conduct the quantitative evaluation of the learners' perception towards blogging, they were given a Likert Scale questionnaire (Appendix 3). Table 7 shows the means and percentage of the responses to each alternative in the questionnaire.

\begin{tabular}{|c|c|c|c|c|c|c|c|c|}
\hline $\begin{array}{c}\text { Questio } \\
\text { n }\end{array}$ & \multicolumn{2}{|c|}{ A } & \multicolumn{2}{c|}{ B } & \multicolumn{2}{c|}{ C } & \multicolumn{2}{c|}{ D } \\
\hline & $\begin{array}{c}\text { MEA } \\
\text { N }\end{array}$ & $\begin{array}{c}\text { Percentag } \\
\text { e }\end{array}$ & $\begin{array}{c}\text { MEA } \\
\text { N }\end{array}$ & $\begin{array}{c}\text { Percentag } \\
\text { e }\end{array}$ & $\begin{array}{c}\text { MEA } \\
\text { N }\end{array}$ & $\begin{array}{c}\text { Percentag } \\
\text { e }\end{array}$ & $\begin{array}{c}\text { MEA } \\
\text { N }\end{array}$ & $\begin{array}{c}\text { Percentag } \\
\text { e }\end{array}$ \\
\hline 1 & 0.2 & $20 \%$ & 0.1 & $10 \%$ & 0.4 & $40 \%$ & 0.3 & $30 \%$ \\
\hline 2 & 0.7 & $70 \%$ & 0.3 & $30 \%$ & 0.0 & $0 \%$ & 0.0 & $0 \%$ \\
\hline 3 & 0.4 & $40 \%$ & 0.6 & $60 \%$ & 0.0 & $0 \%$ & 0.0 & $0 \%$ \\
\hline 4 & 0.8 & $80 \%$ & 0.2 & $20 \%$ & 0.0 & $0 \%$ & 0.0 & $0 \%$ \\
\hline 5 & 0.8 & $80 \%$ & 0.2 & $20 \%$ & 0.0 & $0 \%$ & 0.0 & $0 \%$ \\
\hline 6 & 0.6 & $60 \%$ & 0.3 & $30 \%$ & 0.1 & $10 \%$ & & \\
\hline 7 & 0.3 & $30 \%$ & 0.3 & $30 \%$ & 0.4 & $40 \%$ & & \\
\hline
\end{tabular}

Table 7: Responses to Each Item of the Quantitative Evaluation Questionnaire

Table 7 indicates that most of the learners $(40 \%)$ use weblogs occasionally, while $30 \%$ of them never use it. Moreover, $70 \%$ of the learners strongly agreed that they liked posting their writing assignments on the weblog and $60 \%$ of them agreed that they liked having their classmates comment on their post. $80 \%$ of the learners strongly agreed that blogging encouraged them to write better, and similarly $80 \%$ strongly agreed that generally they found blogging useful. It was $60 \%$ of the learners who used the Internet a lot, while $40 \%$ of them used the Internet less than an hour a day.

Looking at all the information in this part at once, one can easily understand that the learners had a positive attitude towards blogging and it is partially in line with the results pertaining to the performances of the Control Group and the Blogging Group.

\section{$5 \quad$ Discussion and Limitations}

Generally the findings of this study suggest that blogging can be affective in a number of domains, which are the frequency of missed articles, frequency of missed prepositions, and the number of words. Looking back at other studies done in the domain of educational blogging, it is noticed that none of them had investigated the writing performances of the learners from different angles. Accordingly, in some of those studies the results substantially showed that blogging cannot affect the writing skills of the English learners in general. That is why the results available in the literature are not totally in line with those of the current study.

By studying the learners' point of view about blogging it was recognized that they found it to be an interesting activity which helped them improve their writing skills. They believed that blogging had made them more meticulous about their language and it was a good opportunity to learn from the mistakes committed by their classmates. 
This study revealed some insightful findings in the development of writing skills, however, like any other research papers there were also some limitations. The small sample size in this study certainly decreased the statistical power in the quantitative measures.

Moreover, the participants in this study were all male language learners who experienced writing in an interactive situation like weblogs. If female learners had taken part in the same research, the results could have been altered. So the researcher could find out how different genders react to using weblogs as a learning tool.

By the inclusion of two other classes of female language learners in this study, one as the Blogging Group and the other one as the Control Group, the researcher could both, increase the number of participants and also incorporate male and female learners as the participants. Consequently, the results could have been more generalizable.

Finally the number of writing tasks was limited to the time constrain imposed on the researcher as in the selected institute there were only 20 sessions in each semester. So it was not possible to assign more writing tasks and continue the study by the same participants for a longer period.

\section{Conclusion}

The overall findings of this study suggest that weblogs can be integrated into an English class as a beneficial tool. Notwithstanding its advantages, weblogs, exactly like any other learning tool, must be adapted and incorporated appropriately into the activities of an English class in order to make the most out of it. Also weblogs can turn a writing task into an interactive activity. Both the students and the teachers, usually consider writing as an individual activity. But the findings of this study showed that by incorporation of weblogs, students would have more interaction, both with other students and the teacher. Students by blogging enjoy peer editing which, under the supervision of the teacher, is one aspect of blogging and leads to an interactive situation. Some teachers may argue that peer editing may be problematic for the students, with regards to the fact that they are similarly lacking in knowledge of grammar and vocabulary; therefore, they have difficulty providing effective feedback to their classmates. But this problem can be overcome if this is done under the control of the teacher. When the students try to leave a comment, they will be aware of the mistakes more than before, and accordingly they will avoid making the same mistakes in future.

By the way, it may be argued that by modeling correct structures and new vocabulary after each other, learners miss the chance of being creative in a writing activity. But it can be overcome if the teacher confirms all the students' posts at the same time so that they appear in the weblog simultaneously.

In many EFL learning situations there is a limitation in the amount of exposure to learning materials outside the classroom. Blogging provides a situation for the learners to continue their learning experience and come together in a virtual environment. This can be an outstanding feature of blogging, specially in countries where minimum English input is available in normal social situations. It is, therefore, advisable that teachers deploy weblogs in their English classes, while keeping the learners' needs in mind. Many teachers may suppose that such activities like blogging require a considerable amount of time and energy that it does not worth trying. But the current study indicated that English learners showed interest towards blogging and they had a positive attitude towards it. It seemed such a useful and enjoyable activity for them that they showed enthusiasm to continue the same procedure in future. 


\section{References}

Al-Aayed, Banan S. (2009): Blog assisted language learning: The use of blog in language learning in Saudi schools. http://libback.uqu.edu.sa/hipres/ABS/ind10830, accessed April 20, 2011.

Atkinson, Dwight (2003): "L2 writing in the post-process era: Introduction". Journal of Second Language Writing 12: 3-15.

Bloch, Joel (2007): "Abdullah's blogging: A generation 1.5 student enters the blogosphere". Language Learning \& Technology 11, 2: 128-141. http://llt.msu.edu/vol11num2/bloch/default.html, accessed April 20, 2011.

Campbell, Aaron (2005b): "Weblog applications for EFL/ESL classroom blogging: A comparative review". TESL-EJ 9/3: 1-12.

Chang, Jen-Shih/Chang, Yu-Chia (2004): "Computer Assisted Language Learning based on corpora and natural language processing: the experience of project CANDLE". An Interactive Workshop on Language e-Learning (IWLeL): 15-23.

Chastain, Kenneth $\left({ }^{3} 1988\right)$ : Developing second language skills: Theory and practice. San Diego, CA: Harcourt Brace Jovanovich.

Dieu, Barbara (2004): "Blogs for Language Learning". Essential Teacher 1/: 26-30.

Drexler, W./Dawson, K./Ferdig, R.E. (2006): "Collaborative blogging as a means to develop elementary expository writing skills". Electronic Journal for the Integration of Technology in Education 6: 140-160.

Farrell, Henry (2003): The street finds its own use for things. http://www.crookedtimeber.org/archives/00516.html, accessed December 20. 2010.

Fellner, Terry/Apple, Matthew (2006): "Developing writing fluency and and lexical complexity with blogs". The JALT CALL Journal 2: 15-26.

Flower, Linda/Hayes John R. (1981): "A cognitive process theory of writing". College Composition and Communication 32: 365-387.

Holmes, Nicola (2006): The use of a process-oriented approach to facilitate the planning and production stages of writing for adult students of English as a foreign or second language. Retrieved December 9, 2012 from http://www.developingteachers.com.

Jones, Sharla Jeannette (2006): Blogging and ESL writing: A case study of how students responded to the use of Weblogs as a pedagogical tool for the writing process approach in a community college ESL writing class. Doctoral Dissertation, University of Texas. ProQuest Information and Learning Company, UMI: 3254430

Kelley, Michael. John (2008): "The impact of weblogs on the affective states and academic writings of L2 undergraduates". Dissertation Abstract International 69 /4: 1-.

Mitchell, Dan (2003): Thoughts about weblogs in education. Retrieved November 18, 2010 from http://www.teachnology.org/stories/storyReader $\$ 150$

Nunan, David (1999): Second Language Teaching and Learning. Boston: Thomson/Heinle.

O'Donnell, Timothy J. (2006): "Learning English as a foreign language in Korea: Does CALL have a place?". Asian EFL Journal 10: 1-27.

Rezaee, Abbas Ali/Oladi, Samaneh (2008): "The effect of blogging on language learners' improvement in social interactions and writing proficiency". Iranian Journal of Language Studies 2/1: 73-88.

Richardson, Will (2006): Blogs, wikis, podcasts, and other powerful web tools for classrooms. Thousand Oaks, CA: Corwin Press.

Richards, Jack C./Renandya, Willy Ardian (eds.) (2002): Methodology in Language Teaching: An Anthology of Current Practice. Cambridge: Cambridge University Press.

Shokrpour, Nasrin/Fallahzadeh, Hossein F. (2007): "A Survey of the Students and Interns' EFL Writing Problems in Shiraz University of Medical Sciences". Asian EFL Journal 9/1.

Warschauer, Mark (1997):" Computer-mediated collaborative learning: Theory and practice". Modern Language Journal 81: 470-481. 
Weigle, Sara Cushing (2002): Assessing writing. Cambridge: Cambridge University Press.

\section{Appendix 1}

First open-ended questionnaire to study learners' perception of blogging qualitatively.

The following questionnaire was given to the students in Persian.

Name:

Age:

Occupation:

Describe your feelings about using weblogs for doing your class assignments (try to indicate your ideas about all aspects of this tool).

\section{Appendix 2}

Second open-ended questionnaire to study learners' perception of blogging qualitatively.

The following questionnaire was given to the students in Persian.

Name:

Answer the following questions.

1.Do you find blogging a useful technology to improve your writing skills? Why?

2. How do you feel about using weblog for your routine class activities?

3. What do you like the most about blogging?

4. What don't you like about blogging?

5. How have you benefited from blogging?

6. What suggestions do you have for using modern technology in your courses? 